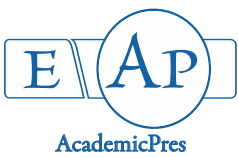

Agina OA et al. (2021)

Notulae Scientia Biologicae

Volume 13, Issue 4, Article number 11046

DOI: $10.15835 / \mathrm{nsb} 13411046$

Research Article

\title{
Molecular detection of Trypanosoma species and haematological alterations in four trypanosome-infected Nigerian horses
}

\author{
Onyinyechukwu A. AGINA ${ }^{1 *}$, John I. IHEDIOHA ${ }^{1}$, \\ Tope E. ADEYEYE ${ }^{1}$, Paschal U. UMEAKUANA², \\ Idoko Sunday IDOKO ${ }^{3}$
}

\author{
${ }^{1}$ University of Nigeria, Faculty of Veterinary Medicine, Department of Veterinary Pathology and Microbiology, Nsukka, 410001 \\ EnuguState,Nigeria; onyinye.noel@unn.edu.ng(*corresponding author);john.ihedioha@unn.edu.ng; tope.adeyeye@yahoo.com \\ ${ }^{2}$ University of Abuja, Faculty of Veterinary Medicine, Department of Veterinary Medicine, \\ Nigeria; paschal.umeakuana@uniabuja.edu.ng \\ ${ }^{3}$ University of Abuja, Faculty of Veterinary Medicine, Department of Veterinary Pathology, Nigeria; idoko.sunday@uniabuja.edu.ng
}

\begin{abstract}
Trypanosomes cause anaemia and are responsible for widespread morbidity and mortality particularly in imported breeds of animals found in sub-tropical and tropical parts of the world. Light microscopy and polymerase chain reaction (PCR) were used to detect trypanosomes in naturally infected Nigerian crossbred horses at Obollo-Afor abattoir, Udenu Local Government Area, Enugu State Nigeria. Blood was collected via the jugular outflow from a total of 200 horses of varying ages and either sex. Conventional procedures were followed during the PCR assay, parasite identification in wet mount, Leishman-stained thin blood and buffy coat smears on glass slides. Light microscopy revealed Trypanosoma species with an elongated, streamlined and tapered body, highly suggestive of T. brucei brucei or its subspecies T. evansi or T. equiperdum. PCR assay produced the expected fragment size of $700 \mathrm{bp}$ specific for ITS-1 region of the 18SrRNA gene of Trypanosoma species in 4 (2\%) of 200 blood samples against the routine blood and buffy coat smear examination, which revealed trypanosomes in $3(1.5 \%)$ out of 200 blood samples. Sex and age were not significantly $(p>0.05)$ associated with the trypanosome infection. One of the Trypanosoma infected anaemic horses had microcytic normochromic anaemia, high erythrocyte sedimentation rate and normal leukocyte count, while one of the Trypanosoma species infected non-anaemic horses had erythrocytic parameters and ESR values that are within the reference range, with leukocytosis. It was concluded that the prevalence of equine trypanosomosis was very low, and it's characterized by mild to moderate anaemia in clinical cases.
\end{abstract}

Keywords: anaemia; Nigerian horses; PCR assay; prevalence; Trypanosoma species

\section{Introduction}

Trypanosomosis is a disease caused mainly by trypanosomes such as Trypanosoma vivax, T. congolense, T. brucei, T. equiperdum and T. evansi, and which is responsible for huge production losses in the livestock industry (Seidl et al., 1998). Trypanosomes are extracellular, microscopic and elongated protozoan parasites

Received: 11 Aug 2021. Received in revised form: 22 Sep 2021. Accepted: 18 Oct 2021. Published online: 02 Nov 2021.

From Volume 13, Issue 1, 2021, Notulae Scientia Biologicae journal uses article numbers in place of the traditional method of continuous pagination through the volume. The journal will continue to appear quarterly, as before, with four annual numbers. 
belonging to the genus Trypanosoma that thrive in the peripheral blood circulation and in tissues (Radostits et al., 2007). This haemoprotozoan is virulent, inoculable but not contagious, except for Trypanosoma equiperdium that is transmitted by coitus (Radostits et al., 2007). These parasites are commonly found in the tropics and affect a wide variety of domestic and wild animals (Ugochukwu, 2009). It causes high morbidity and high mortality in infected herds, thereby making the disease very difficult to manage in endemic areas (Ugochukwu, 2009).

These trypanosomes of veterinary and economic importance are cyclically transmitted by tse-tse (Glossina spp.) and mechanically transmitted by other biting flies such as Tabanus spp. and Stomoxys calcitrans (Mijares et al., 2010). The severity of the infection is dependent upon the species, co-infection, age and nutritional status of the horse. A disease condition known as Nagana (African trypanosomosis) is caused by $T$. congolense and $T$. brucei brucei in horses while Surra is caused by $T$. evansi and T. vivax. In general, trypanosomosis is characterized by macrocytic hypochromic anaemia, leukopenia, thrombocytopenia, increased erythrocyte sedimentation rate, monocytosis, increased serum activities of liver enzymes, elevated blood urea nitrogen, hypoalbuminemia and hypergammaglobulinemia, fever, anorexia, dullness, weight loss, tissue damage, immunosuppression and in some cases, death (Anosa, 1988a, 1988b; Kihurani et al., 1994; Auty et al., 2008; Mijares et al., 2010; Hussain et al., 2014; Agina and Ihedioha, 2016; Agina, 2017). Trypanosomosis caused by $T$. brucei brucei infection characterized by presence of subcutaneous oedema of the dependent areas such as the ventral abdominal wall, thorax and limbs, keratoconjunctivitis, ataxia and paralysis (Radostits et al., 2007). Trypanosoma vivax or T. congolense usually produce the chronic form and may cure spontaneously in local breeds (Taylor and L-Authie, 2004). Surra (Mal de Caderas) caused by Trypanosoma evansi, is an endemic disease of mainly horses and camels in the tropics and subtropics. The disease is associated with fever, subcutaneous oedema, nervous signs and death. Trypanosoma evansi is transmitted mechanically by blood sucking horse flies, from one susceptible host to another and does not possess the insect stage (Lai et al., 2008; Luckins, 1998). At the molecular level, T. evansi is said to possess an akinetoplastic DNA (complete loss of kinetoplastid DNA) and this locks the trypanosome in the bloodstream form (Lai et al., 2008). Dourine (mal de coit) is a venereal disease of donkeys, horses, mules and water buffaloes caused by T. equiperdum. The disease is characterized by low morbidity and high mortality. Trypanosoma equiperdum is one of the pathogenic trypanosomes that does not require an arthropod vector for its transmission, and at the molecular level, they possess partial loss of kDNA (dyskinetoplastid) which also locks it in the bloodstream stage (Lai et al., 2008). Natural transmission occurs only by coitus as the organism inhabits the mucosa of genital organs. Donkeys have some degree of resistance to the infection but may be compromised by any form of stress (Agina, 2017).

The horse is a domesticated animal used for transport, draft, sports, recreation, research purposes and as food (source of meat) worldwide) (Edwards, 1994). The African breeds of horses include the Dongola breed, West African Barb, Nigerian local (Arewa) breed of horses and their crosses with Arabian, Dongola, Barb and Sudanese breeds. Their coat colours are a deep reddish bay, sometimes chestnut or black (Hendricks and Dent, 2007). They are commonly found in the northern part of Nigeria (Ihedioha and Agina, 2013, 2014). The largest category of horses in this region is the mixed 'Arewa' breed and is kept for rides during festivals (Garba et al., 2011).

There is little information on the molecular prevalence of Trypanosoma species in Nigerian horses. Therefore, this study was conducted to ascertain the prevalence of naturally occurring trypanosome infections in Nigerian horses at Obollo Afor horse lairage, Udenu Local Government, Enugu State, Nigeria and to determine the haemato-pathological features of the disease. To the best of our knowledge, this is the first molecular detection of trypanosomes in Nigerian horses. 


\section{Materials and Methods}

\section{Ethical approval}

This research was done in accordance with the Ethics and Regulations guiding the use of animals as approved by the University of Nigeria Senate committee on Medical and Research ethics, ECUN/77932.

\section{Study design}

The study was a cross-sectional survey of Nigerian horses at the Obollo Afor horse lairage, Udenu Local Government Area, Enugu State, Nigeria. Obollo Afor is located between latitude 6 ${ }^{\circ} 54^{\prime} 56^{\prime \prime}$ and longitude $7^{\circ}$ $30^{\prime} 55^{\prime \prime}$. The Obollo Afor horse lairage is the transit and sales point for horses mainly of the Arabian, Barb-Arab and Dongola breeds and cross-bred horses shipped from Northern to Eastern Nigeria for agricultural and teaching purposes (Ihedioha and Agina, 2013, 2014) The horses are kept in the lairage for 1-4 weeks after arrival before slaughter for meat.

\section{Sample size determination}

To study the status of the prevalence of trypanosome infection, the expected prevalence was considered $2.4 \% .{ }^{10}$ with confidence limits of $95 \%$ and a desired absolute precision of $5 \%$ to collect a minutes number of samples, according to (Thrusfield, 2005) The number of samples thus calculated was adjusted for finite population and was correlated with 200 samples (200 horses). Blood samples were collected every two weeks throughout the 5-month study period from July - November 2017. These horses were subjected to comprehensive physical examination and aged before blood samples were collected for parasitological evaluations.

\section{Aging of the horses}

The ages of the horses were estimated based on tooth eruption and wear (Ensminger, 1969).

\section{Blood sample collection}

Blood for parasitological and haematological determinations was collected from the jugular outflow at slaughter into ethylenediaminetetraacetic acid $\left(\mathrm{K}_{2}\right.$ EDTA) blood tubes. Blood sample $(125 \mu \mathrm{L})$ for PCR assay were placed in a circular motion onto designated spots on Whatman FTA classic cards (Sigma-Aldrich, USA), the blood was air-dried for 60 minutes. The blood sample-FTA cards were stored at room temperature of approximately $25^{\circ} \mathrm{C}$ until further use.

\section{Parasitological diagnosis}

Trypanosome identification by direct examination techniques

The wet blood film (wet mount) was done by placing a drop of blood on a clean grease-free microscope slide and covering it with a clean cover slip. The wet mount was examined with a light microscope at $10 \times 10$ magnification for the movement of the trypanosomes which is used as a means of identification of the specific Trypanosoma species. A thin blood smear was made with the aid of a clean cover slip after placing about a drop of blood on another clean grease-free microscope slides. The slides were air dried and stained following the Leishman technique and examined under oil immersion using a light microscope at $10 \times 100$ magnification. Identification of parasites was done using morphological description by Hoare (1972).

Parasite concentration technique (microhaematocrit centrifugation/buffy coat technique)

This involved the centrifugation of a microhaematocrit capillary tube containing the blood sample and microscopic examination of the buffy coat/plasma junction (Murray et al., 1977). Two-thirds of the microhematocrit capillary tubes were filled with blood by capillary action and one end was sealed with plasticine. The tubes were placed in a micro-hematocrit centrifuge (Techmel and Techmel, USA) and spun at 10,000 
revolutions per minutes $(1120 \mathrm{xg})$ for 5 minutes. The tubes were cut at the buffy coat/plasma junction and extruded onto a clean microscope slide and covered with a coverslip and examined using a light microscope.

\section{Conventional PCR assay}

Polymerase chain reaction (PCR) primers were selected based on previously published work (Adams et al., 2006). Details of the primers are presented in Table 1.

Table 1. Genus primer for trypanosome species gene amplification

\begin{tabular}{|c|c|c|c|c|}
\hline Parasite & Primer sequence (5'-3' Forward) and Reverse & Gene & $\begin{array}{c}\text { Amplicon size } \\
(\mathrm{bp})\end{array}$ & Reference \\
\hline Trypanosoma spp. & $\begin{array}{c}\text { TRYP3: TGC AAT TAT TGG TCG CGC } \\
\text { TRYP4: CTT TGC TGC GTT CTT }\end{array}$ & ITS-1 & $150-750$ & $\begin{array}{c}\text { Adams et al., } \\
2006\end{array}$ \\
\hline
\end{tabular}

\section{Genomic DNA extraction}

Genomic DNA was extracted from 150 randomly selected designated spots on blood sample-FTA cards using Chelex 100 resin. Briefly, a 5\% w/v suspension of Chelex 100 resin in sterile water was prepared prior to use and stirred to obtain a suspension. Harria Uni-Core disposable punch $(2.0 \mathrm{~mm})$ was used to remove sample discs from the centre of a dried blood sample spot. The discs were placed in a clean RNase/DNase free $1.5 \mathrm{~mL}$ micro centrifuge tube. Discs were washed by adding $1 \mathrm{~mL}$ of sterile water to each sample tube and incubated at room temperature for 10 minutes with occasional vortexing. The water was removed, washing was repeated by adding $1 \mathrm{~mL}$ of sterile water to each sample tube and incubated at room temperature for 10 minutes with occasional vortexing. The samples were centrifuged for 3 minutes at $14,500 \mathrm{rpm}$. The supernatant was removed and discarded. $200 \mu \mathrm{L}$ of Chelex 100 resin suspension was added using a large-bore pipette tip to the sediment. The samples were incubated at $56^{\circ} \mathrm{C}$ for 20 minutes with vortexing every 10 minutes. The samples were vortexed for approximately 15 seconds and incubated at $95^{\circ} \mathrm{C}$ for 10 minutes. The samples were vortexed for approximately for 15 seconds and centrifuged at $14,500 \mathrm{rpm}$ for 5 minutes. The supernatant was transferred (about $150 \mu \mathrm{L}$ ) to a sterile pre-labeled tube being careful to avoid taking the Chelex 100 resin pellet. The eluted DNA was stored at $-20^{\circ} \mathrm{C}$.

\section{PCR analysis}

Polymerase chain reaction was performed in a $25 \mu \mathrm{L}$ final reaction volume comprising $12.5 \mu \mathrm{L}$ of Dream Taq $2 \mathrm{x}$ mix (Thermofisher Scientific, USA), $0.1 \mu \mathrm{L}$ of each primer $(100 \mu \mathrm{M}), 5 \mu \mathrm{L}$ of DNA template, $7.3 \mu \mathrm{L}$ of nuclease free water (Promega, USA). Negative control (template DNA substituted with nuclease free water) and positive test controls (Trypanosoma brucei brucei J10 and Trypanosoma congolense savannah WG81) were incorporated into each run. The PCR tubes were placed in a thermocycler (Bio-Rad, USA). The thermocyclic conditions were as follows: pre-denaturation at $95^{\circ} \mathrm{C}$ for 3 minutes followed by 35 cycles of 95 ${ }^{\circ} \mathrm{C}$ for 1 minute, $54{ }^{\circ} \mathrm{C}$ for 1 minute, $72^{\circ} \mathrm{C}$ for 30 s, and followed by final extension of $72^{\circ} \mathrm{C}$ for 5 minutes. Fifteen microliters of the PCR products were electrophoresed through 1.7\% agarose gel in 1x TAE (Tris-acetic acid-EDTA) buffer at $100 \mathrm{~V}$ for 60 minutes, along with $15 \mu \mathrm{L}$ Hyperladder ${ }^{\mathrm{TM}}$ Marker $100 \mathrm{bp}$ DNA (Bioline, UK). Gels were stained with ethidium bromide at $5 \mu \mathrm{L} / 100 \mathrm{~mL}$ of the agarose gel suspension. Gels were viewed under UV transilluminator (Blook ${ }^{\mathrm{TM}}$, Genedirex). Images were captured using an AlphaImager Hp System (Protein Simple, USA). To prevent cross-contamination, work areas were designated solely for DNA extraction and PCR amplification. All reagent preparation was done in a dedicated biosafety cabinet and was UV illuminated before and at the end of each session to avoid DNA contamination.

\section{Haematological analysis}

The packed cell volume (PCV) was determined by the micro-haematocrit method (Thrall and Weiser, 2002) while haemoglobin concentration ( $\mathrm{Hbc}$ ) was determined by the cyanomethaemoglobin method (Higgins et al., 2008). Red blood cell (RBC) counts and total leukocyte counts (TLC) were carried out by 
haemocytometer method (Thrall and Weiser, 2002). Differential leukocyte count was done by making a blood smear made on clean glass slide and stained following the Leishman technique. The different cells of the leukocytic series were enumerated by the battlement counting method (Thrall and Weiser, 2002). The mean corpuscular values - mean corpuscular volume (MCV) and mean corpuscular haemoglobin concentration (MCHC) was calculated using the standard formulae (Coles, 1986). Erythrocyte sedimentation rate was determined by Westergren method (Coles, 1986).

\section{Ethical issues}

This research was done in accordance with the Ethics and Regulations guiding the use of animals as approved by the University of Nigeria Senate committee on Medical and Research ethics, ECUN/77932.

\section{Statistical analysis}

Data obtained from this study were subjected to descriptive statistics with the aid of the Statistical Package for Social Sciences (SPSS) version 16 (Chicago, USA). Chi-square or Fisher exact test was used to analyse for associations between sex (male and female), horse age (young, adult, and old), and infection with trypanosomes. Values of $\mathrm{p}<0.05$ were considered statistically significant. The prevalence of trypanosome infections in the horses is expressed as the percentage of the sampled horses.

$$
\text { Prevalence }=\frac{\text { Number of Trypanosome positive horses }}{\text { Number of horses sampled }} \times 100
$$

\section{Results}

\section{Demographic data on the horses sampled.}

Out of the 200 horses sampled, 7 (3.5\%) were young (1-4 years old), 175 (87.5\%) were adults (5-11 years old), and 18 ( $9 \%$ ) were old (>12 years old). A total of 138 (69.0\%) were females (mares) while $62(31.0 \%)$ were males (stallions) (Table 2).

Table 2. Distribution of Trade horses sampled by their demographic characteristics

\begin{tabular}{|l|c|c|}
\hline Demographic characteristics & Total number sampled & Percentage (\%) \\
\hline \multicolumn{3}{|c|}{ Age } \\
\hline Young (1-4 years) & 7 & 3.5 \\
\hline Adult (5-11 years) & 175 & 87.5 \\
\hline Old (>12 years) & 18 & 9 \\
\hline \multicolumn{3}{|c|}{ Sex } \\
\hline Female (Mare) & 138 & 69 \\
\hline Male (Stallion) & 62 & 31 \\
\hline \multicolumn{2}{|c|}{ Health Status } \\
\hline Trypanosoma positive horses & 4 & 2.0 \\
\hline Trypanosoma negative horses & 196 & 98 \\
\hline
\end{tabular}

\section{Trypanosome identification}

None of the wet mounts examined under the light microscope showed evidence of movement/motility (No motile parasites were seen). The trypanosome species identified in a Leishman-stained thin blood smear under x1000 magnification of the light microscope was highly suggestive of T. brucei (Figure 1). It has an elongated body, a streamlined and tapered shape, and its kinetoplast lies near the basal body. A single flagellum runs towards the anterior end, and along the body surface, the flagellum is attached to the cell membrane forming an undulating membrane (Figure 1). The buffy coat concentration technique yielded one positive result (Table 5). 


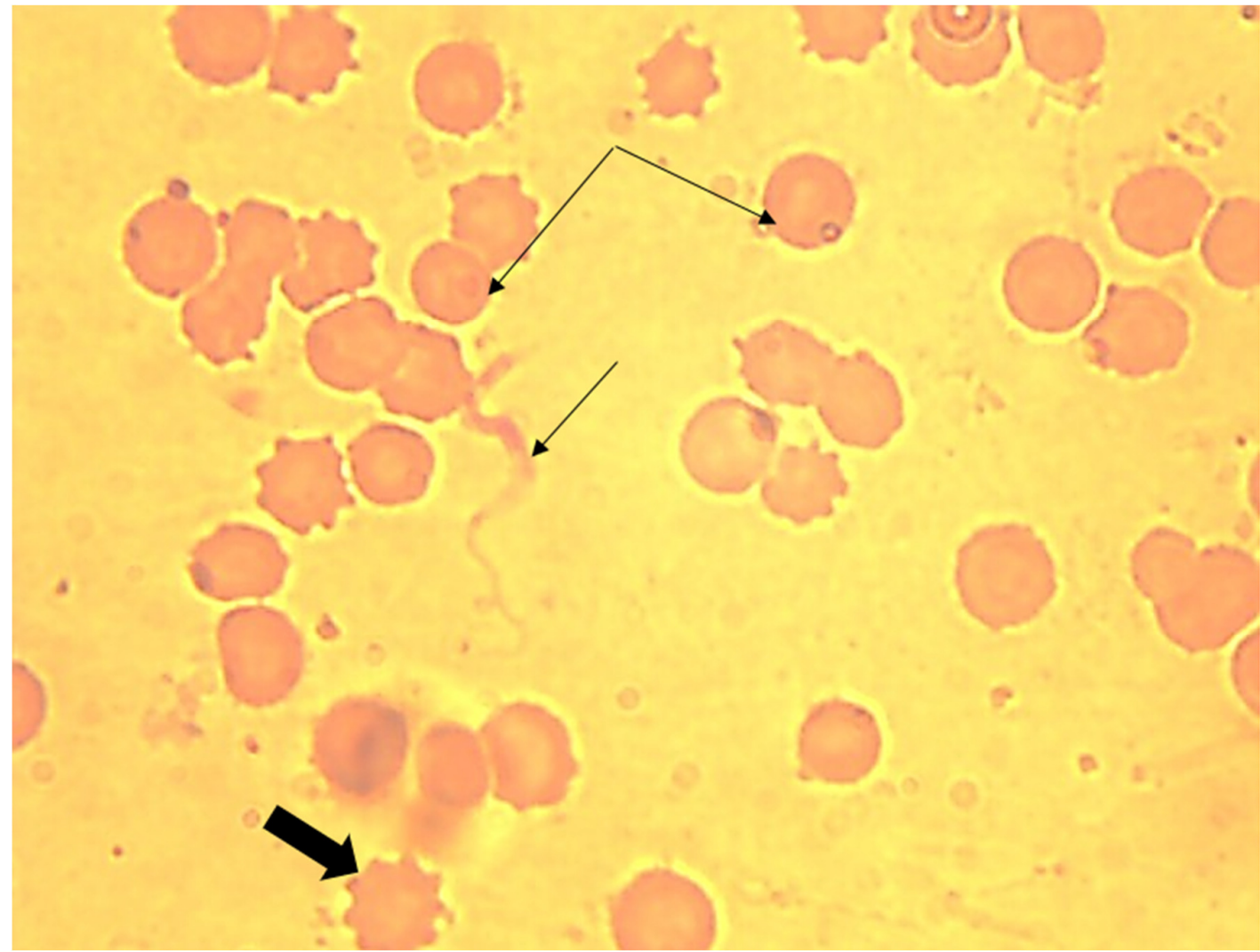

Figure 1. The blood picture of Trypanosoma species (arrow) infected horses showing the echinocyte (block arrow) and red blood cells of different sizes (double arrow) X1000 magnification

\section{Prevalence of trypanosome infections in the horses}

The Leishman-stained blood smears showed that 3 (1.5\%) out of the 200 horses sampled were found to have trypanosomes in blood (trypanosome positive), while 197 (98.5\%) were trypanosome negative (Table 2). The females (mares) had a $2.2 \%$ prevalence rate of trypanosomosis while males (stallion) had $1.6 \%$ prevalence rate (Table 3$)$. There were no significant association $(\mathrm{P}=0.176)$ between the prevalence of trypanosomosis and sex of horses (Table 3 ).

Table 3. Chi-square test-based association analysis of trypanosomosis in male and female trade horses

\begin{tabular}{|l|c|c|c|c|c|}
\hline \multicolumn{1}{|c|}{ Sex } & $\begin{array}{c}\text { Number } \\
\text { sampled }\end{array}$ & $\begin{array}{c}\text { Number } \\
\text { Positive }\end{array}$ & Chi-square & $\begin{array}{c}\text { Fisher's exact } \\
\text { test }\end{array}$ & P value \\
\hline Female & 138 & $3(2.2 \%)$ & 1.834 & 1.356 & 0.176 \\
\hline Male & 62 & $1(1.6 \%)$ & & & \\
\hline
\end{tabular}

The young horses had the highest prevalence of trypanosomosis (14.3\%), followed by the old horses (5.6\%), and $1.1(\%)$ prevalence of trypanosomosis in adult horses (Table 4). There was no significant association $(\mathrm{P}=0.077)$ between the prevalence of trypanosomosis and age of horses (Table 4). 
Table 4. Fisher's exact test-based association analysis of trypanosomosis in trade horses of different ages

\begin{tabular}{|l|c|c|c|c|}
\hline \multicolumn{1}{|c|}{ Age } & Number sampled & Number Positive & $\begin{array}{c}\text { Chi-square } \\
\text { (Fisher's exact test) }\end{array}$ & P value \\
\hline Young & 7 & $1(14.3)$ & 6.522 & 0.077 \\
\hline Adult & 175 & $2(1.1)$ & & \\
\hline Old & 18 & $1(5.6)$ & & \\
\hline
\end{tabular}

\section{Clinical and haematological findings}

Twenty-six (13\%) of sampled horses were found anaemic. Only $2(7.7 \%)$ out of the 26 anaemic horses were trypanosome positive while $2(1.1 \%)$ out of the 174 non-anaemic horses had trypanosome parasite. Trypanosome was present in 2 anaemic horses and 2 non-anaemic horses (Table 5). The anaemic horses had lower PCV (22\% and 15\%), Hbc $(6.05 \mathrm{~g} / \mathrm{dl}$ and $6.70 \mathrm{~g} / \mathrm{dl})$ and $\mathrm{RBC}$ counts $\left(4.52 \times 10^{6} / \mu \mathrm{L}\right.$ and $\left.4.50 \times 10^{6} / \mu \mathrm{L}\right)$ than those of non-anaemic horses ( $41.5 \%$ and 36\%). One of the anaemic horses had mild normocytic normochromic while another had moderate microcytic normochromic anaemia. The white cell count of the non-anaemic horses was high $\left(15.70 \times 10^{3} / \mu \mathrm{L}\right.$ and $\left.17.45 \times 10^{3} / \mu \mathrm{L}\right)$ when compared to the anaemic horses $\left(10.95 \times 10^{3} / \mu \mathrm{L}\right.$ and $\left.8.75 \times 10^{3} / \mu \mathrm{L}\right)$. The erythrocyte sedimentation rate of horse 33 (anaemic horse) was higher $\left(75 \mathrm{~mm}^{3}\right)$ than that of horse 170 , the non-anaemic horse $\left(28.26 \mathrm{~mm}^{3}\right)$. Clinical findings observed in the anaemic horses were paleness of the mucous membrane, weakness and mild tick infestation. One horse had opaque cloudiness of the eye (Table 5). Few ticks were found attached especially in the inguinal regions of all four horses.

Table 5. Clinical and haematological findings of four horses with trypanosomosis

\begin{tabular}{|c|c|c|c|c|}
\hline $\begin{array}{c}\text { Clinical Signs and } \\
\text { haematological } \\
\text { parameters }\end{array}$ & Horse 4 & Horse 18 & Horse 33 & Horse 170 \\
\hline Age (years) & 1 & 4 & 5 & 12 \\
\hline Sex & $\mathrm{M}$ & $\mathrm{F}$ & $\mathrm{F}$ & $\mathrm{F}$ \\
\hline Breed & Crossbred & Crossbred & Crossbred & Crossbred \\
\hline $\begin{array}{l}\text { Clinicaland } \\
\text { haematological } \\
\text { findings }\end{array}$ & $\begin{array}{l}\text { Anaemia, pale mucous } \\
\text { membrane, mild tick } \\
\text { infestation }\end{array}$ & $\begin{array}{c}\text { Cachexia, opaque } \\
\text { cloudiness of the eye, } \\
\text { leukocytosis, mild tick } \\
\text { infestation }\end{array}$ & $\begin{array}{c}\text { Anaemia, weakness, pale } \\
\text { mucous membrane, mild } \\
\text { tick infestation }\end{array}$ & $\begin{array}{c}\text { Mild tick infestation, lame, } \\
\text { leukocytosis }\end{array}$ \\
\hline Wet mount & - & - & - & - \\
\hline Buffy coat & - & - & + & - \\
\hline $\begin{array}{l}\text { Leishman stain thin- } \\
\text { blood smear }\end{array}$ & + & + & - & - \\
\hline PCR assay & + & + & + & + \\
\hline $\begin{array}{c}\text { PCV (\%) } \\
{[31.5-53.50]^{\circ}}\end{array}$ & 22 & 41.5 & 15 & 36 \\
\hline $\begin{array}{c}\mathrm{Hbc}(\mathrm{g} / \mathrm{dL}) \\
{[11.53-19.86]}\end{array}$ & 6.05 & 12.11 & 6.70 & 13.46 \\
\hline $\begin{array}{c}\mathrm{RBC} \text { count }\left(\mathrm{x} 10^{6} / \mu \mathrm{l}\right) \\
{[6.46-11.16]^{\circ}}\end{array}$ & 4.52 & 9.06 & 4.50 & 7.35 \\
\hline $\begin{array}{c}\mathrm{MCV}(\mathrm{fl}) \\
{[38.37-60.96]}\end{array}$ & 48.67 & 45.81 & 33.33 & 48.98 \\
\hline $\begin{array}{l}\mathrm{MCHC}(\mathrm{g} / \mathrm{dL}) \\
{[27.67-55.03]^{\circ}}\end{array}$ & 27.50 & 29.18 & 44.67 & 37.39 \\
\hline $\begin{array}{c}\mathrm{ESR}\left(20 \mathrm{mins} / \mathrm{mm}^{3}\right) \\
{[21.0-37.10]^{*}}\end{array}$ & ND & ND & 75 & 28.26 \\
\hline $\begin{array}{c}\text { WBC count } \\
\left(\mathrm{x} 10^{3} / \mu \mathrm{l}\right) \\
{[5.40-13.90]^{\circ}}\end{array}$ & 10.95 & 15.70 & 8.75 & 17.45 \\
\hline
\end{tabular}

Note: M - Male; F - Female; ND: Not done; PCV: Packed cell Volume; Hb: Haemoglobin concentration; RBC: Red blood cell; MCV: Mean corpuscular volume; MCHC: Mean corpuscular haemoglobin concentration; ESR: Erythrocyte sedimentation rate; WBC: White blood cell.

Reference range of values for haematological parameters are in parentheses. 


\section{Conventional PCR}

The generic PCR based assay produced an amplicon size of $700 \mathrm{bp}$ of internal transcribed spacer-1 region of 18srRNA gene of trypanosome species (Figure 2), in 4 (2\%) out of 200 sampled horses. The amplicon size of our samples was same with the positive control, Trypanosoma brucei brucei J10. The infection confirmed in Horses 18 and 170 (Table 5) by PCR were subclinical based on the absence of anaemia.

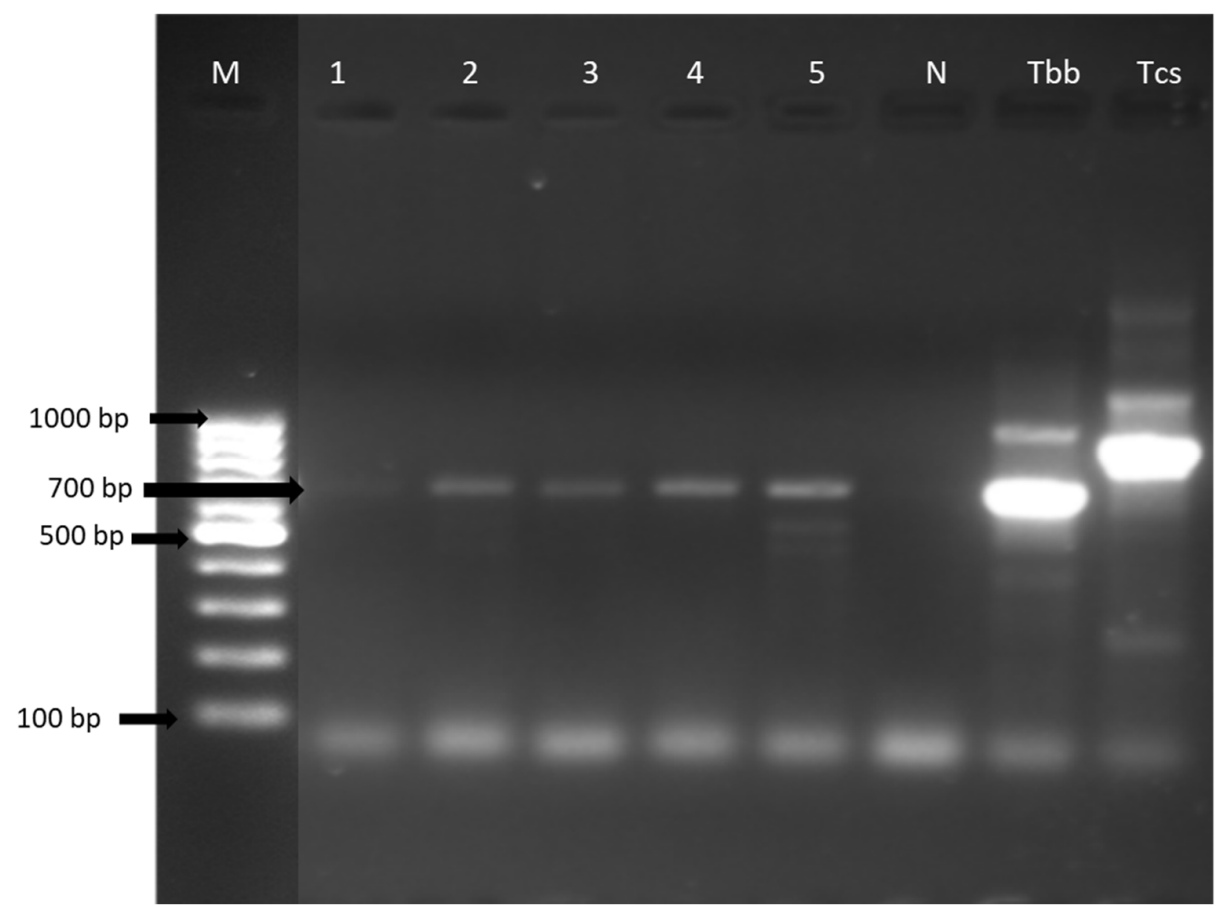

Figure 2. 1.7\% agarose gel electrophoresis image showing a $700 \mathrm{bp}$ band for the PCR amplification of Internal transcribed spacer- 1 (ITS-1) region of the 18 Sribosomal RNA gene of Trypanosome species Lane M: 100 bp DNA Marker (Bioline); Lane 1: Negative horse sample; Lanes 2 - 5: positive horse samples; Lane N: Negative control (no DNA template); Lane Tbb (Trypanosoma b. brucei) J10: positive test control; Lane Tcs (Trypanosoma congolense savannah) WG81 positive test control. Bands were visualized by staining with ethidium bromide.

\section{Discussion}

Our PCR amplicon size compared favourably with that of the positive control, Trypanosoma brucei brucei $\mathrm{J} 10$ and this suggests that the amplified species maybe T. brucei brucei, T. evansi or T. equiperdum. Trypanosoma evansi or T. equiperdum were suggested because the parasite was detected in horses and are indistinguishable from each other ( $\mathrm{Li}$ et al., 2007). There are several speculations or controversy that they might all be the same species and certainly closely related to T. brucei ( Lun et al., 1992; Lai et al., 2008; Carnes et al., 2015; Wen et al., 2016).

In this study, the prevalence of trypanosome infection was low (2.0\%), and this agreed with a previous study in Eastern Nigeria where 0\% prevalence was reported after 100 horses were sampled (Unpublished), followed by prevalence rate of $2.4 \%$ reported in 2016 (Agina and Ihedioha, 2016). Trypanosome identification in both studies were performed by light microscopy. The low prevalence rate recorded in this study was not in agreement with a prevalence study in Gambia where $45.5 \%$ was documented (Faye et al., 2001) and 91\% documented in 2008 (Pinchbeck et al., 2008), with T. vivax being the most prevalent Trypanosoma species using PCR (Pinchbeck et al., 2008). The finding of a trypanosome in one buffy coat smear could be due to low 
parasitemia or that the horse might be presymptomatic or a chronic carrier, as only one trypanosome was found on an entire thin blood smear (Figure 1). In addition, there is also a possibility that the low prevalence rate might have been underestimated as small volume of blood was taken from a horse which is a large animal, and randomly selected punches from FTA cards were utilised for the PCR analysis (Cox et al., 2010). Also, the low parasitemia could be because the horses might be under chemotherapy or the infection was not a recent one. The finding of a low prevalence rate of trypanosome infection in Nigerian horses as observed in this study may be attributed to the use of light microscopic identification of the parasites and conventional PCR. Nested, hemi-nested PCR and PCR-based single strand conformation polymorphism (PCR-SCPP) are most sensitive in detection of trypanosomes (Desquesnes and Tresse, 1996; Wen et al., 2016): Microscopy is labour intensive, less sensitive and cannot be used to correctly differentiate between species, between current and previous infections and may not detect the parasites in blood in case of low parasitemia or during chemotherapy, thereby leading to false negative results (Desquesnes and Dávila, 2002; Li et al., 2007). For example, microscopic technique cannot differentiate between Trypanosoma brucei, T. evansi and T. equiperdum because of the morphological similarity that exists between them, except through the molecular composition of their kinetoplast DNA (kDNA) (Sánchez et al., 2015). Analysis of their total ITS sequences showed a high degree of homology by phylogenetic analysis (Wen et al., 2016). PCR is very sensitive that parasitemia as low as 10 parasites per milliliter of blood can be detected (Desquesnes and Dávila, 2002; Li et al., 2007). Molecular techniques such as PCR-SCPP are more sensitive and precise in the differentiation of these three members of the subgenus Trypanozoon and provided evidence to further support the notion that $T$. evansi and $T$. equiperdum could be subspecies or strains of T. brucei (Wen et al., 2016).

Furthermore, the low prevalence rate of equine trypanosomosis could be that the environmental conditions in Northern Nigeria where these horses are reared are not favourable for the growth and survivability of the tse-tse or biting fly, and these horses only come down with the infection when they are brought to the South-Eastern Nigeria for sale and later slaughtered for meat.

The finding of mild normocytic normochromic anaemia in one of the Trypanosoma infected horses and moderate microcytic hypochromic in other horse is not in agreement with Agina and Ihedioha (2016) who reported macrocytic hypochromic anaemia in the horse. Therefore, we presumed that the infection is subclinical and the major aberrant alterations in the haematological parameters such as leukopenia are yet to manifest. Leukopenia is a major manifestation of trypanosomosis as this parasite causes myeloid hypoplasia (Stockham and Scott, 2008). The trypanosome positive horses with normal erythrocytic parameters might be chronic or asymptomatic carriers. The high erythrocyte sedimentation rate in one of the anaemic horses agrees with Agina and Ihedioha (2016) and was attributed to a smaller number of erythrocytes suspended in the plasma.

\section{Conclusions}

The prevalence of trypanosome infections in the horses sampled is $2.0 \%$ and $T$. brucei or its subspecies T. evansi or T. equiperdum might be the prevalent trypanosome species. The low prevalence of trypanosomosis could be due to absence of tsetse and biting flies in the Northern Nigeria where the horses were sourced, natural resistance of indigenous horses to trypanosome infection, and/or chronically low parasitaemias. In addition, there might be a possibility of underestimation of prevalence as small volume of blood was collected from a large animal (horse) for analysis. In our future study, species-specific primers for T. brucei, T. evansi and T. equiperdum, and sequencing of PCR amplicons shall be done to further confirm the parasite. Also, repeated testing shall be employed to ascertain if the estimated prevalence rate will increase. 


\section{Authors' Contributions}

OAA: Data curation; formal analysis; Investigation; Methodology; Resources; Software; Validation; Writing-original draft; Writing-review \& editing. JII: Conceptualization; Formal analysis; Methodology; Project administration; Resources; Supervision; Validation; Writing-review \& editing. TEA: Data curation; Formal analysis; Investigation; Methodology; Validation. PUU: Data curation; Investigation; Methodology; Resources; Writing-review \& editing. SI: Data curation; Formal analysis; Investigation; Methodology; Software; Writing-review \& editing.

All authors read and approved the final manuscript.

Ethical approval (for researches involving animals or humans)

This research was done in accordance with the Ethics and Regulations guiding the use of animals as approved by the University of Nigeria Senate committee on Medical and Research ethics, ECUN/77932.

\section{Acknowledgements}

We greatly appreciate the assistance of Prof. Wendy Gibson, School of Biological Sciences, University of Bristol, UK who performed the molecular aspect of this work and graciously provided the positive control used in each PCR run. We also appreciate the technical assistances offered by the head of the Obollo Afor horse lairage, and the Department of Veterinary Pathology and Microbiology, University of Nigeria Nsukka.

\section{Conflict of Interests}

The authors declare that there are no conflicts of interest related to this article.

\section{References}

Abbasi HIR, Sahito HA, Sanjrani MI, Abbasi F, Memon MA, Menghwar DR, Kaka NA, Shah MN, Memon M (2014). A disease complex pathogen "trypanosoma congolense" transmitted by tsetse fly in donkeys. Herald Journal of Agriculture and Food Science Research 2(1):44-48.

Adams ER, Malele II, Msangi AR, Gibson WC (2006). Trypanosome identification in wild tsetse populations in Tanzania using generic primers to amplify the ribosomal RNA ITS-1 region. Acta Tropica 100(1-2):103-109. https://doi.org/10.1016/j.actatropica.2006.10.002

Agina OA (2017). Haematology and clinical biochemistry findings associated with equine diseases - a review. Notulae Scientia Biologicae 9(1):1-21. https://doi.org/10.15835/nsb919939

Agina OA, Ihedioha JI (2016). The haematological and serum biochemistry findings associated with natural trypanosome infection in Nigerian horses. In: Proceedings of the 41st Nigerian Society of Animal Production, Ogun State, Nigeria, pp 74-77.

Anosa VO (1988a). Haematological and biochemical changes in human and animal trypanosomiasis. Part I. Revue d'elevage et de Medecine Veterinaire des Pays Tropicaux 41(1):65-78.

Anosa VO (1988b). Haematological and biochemical changes in human and animal trypanosomiasis. Part II. Revue d'elevage et de Medecine Veterinaire des Pays Tropicaux 41(2):151-164.

Auty H, Mundy A, Fyumagwa RD, Picozzi K, Welburn S, Hoare R (2008). Health management of horses under high challenge from trypanosomes: a case study from Serengeti, Tanzania. Veterinary Parasitology 154(3-4):233-241. https://doi.org/10.1016/j.vetpar.2008.02.034 
Carnes J, Anupama A, Balmer O, Jackson A, Lewis M, Brown R, ... Schnaufer A (2015). Genome and phylogenetic analyses of Trypanosoma evansi reveal extensive similarity to T. brucei and multiple independent origins for dyskinetoplasty. PLoS Neglected Tropical Diseases 9(1):e3404. https://doi.org/10.1371/journal.pntd.0003404

Coles E (1986). Veterinary clinical pathology. WB Saunders Company USA.

Cox AP, Tosas O, Tilley A, Picozzi K, Coleman P, Hide G, Welburn SC (2010). Constraints to estimating the prevalence of trypanosome infections in East African zebu cattle. Parasites and Vectors 3(1):1-8. https://doi.org/10.1186/1756-3305-3-82

Desquesnes M, Dávila AMR (2002). Applications of PCR-based tools for detection and identification of animal trypanosomes: a review and perspectives. Veterinary Parasitology 109(3-4):213-231. https://doi.org/10.1016/s0304-4017(02)00270-4

Desquesnes M, Tresse L (1996). Evaluation of sensitivity of PCR for detecting DNA of Trypanosoma vivax with several methods of blood sample preparations. Revue d'elevage et de Medecine Veterinaire Des Pays Tropicaux $49(4): 322-327$.

Edwards E (1994). The Encyclopedia of the Horse. Dorling Kindersley.

Ensminger M (1969). Horses and Horsemanship. $4^{\text {th }}$ Ed. The Interstate.

Faye D, Pereira PJL, Almeida D, Goossens B, Osaer S, Ndao M, ... Geerts S (2001). Prevalence and incidence of trypanosomosis in horses and donkeys in the Gambia. Veterinary Parasitology 101:101-114. https://doi.org/10.1016/s0304-4017(01)00503-9

Garba UM, Sackey AKB, Agbede RIS, Tekdek LB, Bisalla M (2011). Serum urea and creatinine levels in Nigerian local horses naturally infected with Babesia. Pakistan Veterinary Journal 31(2):163-165.

Hendricks B, Dent A (2007). International Encyclopedia of the Horse (Revised). University of Oklahoma Press.

Higgins TE, Beutler BT, Doumas (2008). Measurement of haemoglobin in blood. In: Burtis CA, Ashwood ER, Bruns D (Eds). Tietz Fundamentals of Clinical Chemistry. Saunders Elsevier USA, pp 524-525.

Hoare C (1972). The trypanosomes of mammals. Blackwell Scientific Publications.

Ihedioha JI, Agina OA (2014). Haematological profile of Nigerian horses in Obollo-Afor, Enugu State. Journal of Veterinary and Applied Sciences 4(1):1-8.

Ihedioha JI, Agina OA (2013). Serum biochemistry profile of Nigerian horses (Equus caballus, Linnaeus 1758). Animal Research International 10(3):1826-1833.

Kihurani DO, Nantulya VM, Mbiuki SM, Mogoa E, Nguhiu-Mwangi J, Mbithi PM (1994). Trypanosoma brucei, T. congolense and T. vivax infections in horses on a farm in Kenya. Tropical Animal Health and Production 26(2):95-101. https://doi.org/10.1007/BF02239908

Lai DH, Hashimi H, Lun ZR, Ayala FJ, Lukes J (2008). Adaptations of Trypanosoma brucei to gradual loss of kinetoplast DNA: Trypanosoma equiperdum and Trypanosoma evansi are petite mutants of T. brucei. Proceedings of the National Academy of Sciences of the United States of America 105(6):1999-2004. https://doi.org/10.1073/pnas.0711799105

Li FJ, Gasser RB, Lai DH, Claes F, Zhu XQ, Lun, ZR (2007). PCR approach for the detection of Trypanosoma brucei and T. equiperdum and their differentiation from T. evansi based on maxicircle kinetoplast DNA. Molecular and Cellular Probes 21(1):1-7. https://doi.org/10.1016/j.mcp.2006.03.009

Luckins A (1998). Epidemiology of Surra: unanswered questions. Journal of Protozoology Research 8:106-119. https://doi.org/10.32268/jprotozoolres.8.3_106

Lun ZR, Brun R, Gibson W (1992). Kinetoplast DNA and molecular karyotypes of Trypanosoma evansi and Trypanosoma equiperdum from China. Molecular and Biochemical Parasitology 50(2):189-196. https://doi.org/10.1016/0166-6851(92)90215-6

Mijares A, Vivas J, Abad C, Betancourt M, Piñero S, Proverbio F, Marín R, Portillo R (2010). Trypanosoma evansi: Effect of experimental infection on the osmotic fragility, lipid peroxidation and calcium-ATPase activity of rat red blood cells. Experimental Parasitology 124(3):301-305. https://doi.org/10.1016/j.exppara.2009.11.002

Murray M, Murray PK, McIntyre WI (1977). An improved parasitological technique for the diagnosis of African trypanosomiasis. Transactions of the Royal Society of Tropical Medicine and Hygiene 71(4):325-326. https://doi.org/10.1016/0035-9203(77)90110-9

Pinchbeck GL, Morrison LJ, Tait A, Langford J, Meehan L, Jallow S, ... Christley RM (2008). Trypanosomosis in The Gambia: prevalence in working horses and donkeys detected by whole genome amplification and PCR, and evidence for interactions between trypanosome species. BMC Veterinary Research 4:1-7. https://doi.org/10.1186/1746-6148-4-7 
Radostits O, Gay C, Hinchcliff K, Constable P (2007). Veterinary medicine: a textbook of the diseases of cattle, sheep, pigs, goats, and horses. $10^{\text {th }}$ Ed. Elsevier Saunders USA.

Sánchez E, Perrone T, Recchimuzzi G, Cardozo I, Biteau N, Aso P, Mijares A, Baltz T, Berthier D, Balzano-Nogueira L, Gonzatti M (2015). Molecular characterization and classification of Trypanosoma spp. Venezuelan isolates based on microsatellite markers and kinetoplast maxicircle genes. Parasites and Vectors 8(1):1-11. https://doi.org/10.1186/s13071-015-1129-2

Seidl, A, Moraes AS, Aguilar R, Silva MS (1998). A financial analysis of treatment strategies for Trypanosoma evansi in the Brazilian Pantanal. Preventive Veterinary Medicine 33(1-4):219-234. https://doi.org/10.1016/s01675877(97)00049-4

Stockham SL, Scott MA (2008). Fundamentals of veterinary clinical pathology. $2^{\text {nd }}$ Ed. Blackwell Publishing USA.

Taylor K, Authie EML (2004). 18 pathogenesis of animal trypanosomiasis. In: Maudlin I, Holmes P, Miles M (Eds). The Trypanosomiases. Cromwell Press.

Thrall MA, Weiser MG (2002). Hematology. In: Hendrix CM (Ed). Laboratory Procedures for Veterinary Technicians (4th ed), Mosby, pp 29-74.

Thrusfield M (2005). Veterinary Epidemiology. $2^{\text {nd }}$ Ed. Blackwell Science Limited.

Ugochukwu E (2009). Animal trypanosomiasis in Africa: aetiology and epidemiology. Animal Research International 5(1). https://doi.org/10.4314/ari.v5i1.48718

Wen Y, Lun Z, Zhu X, Hide G, Lai D (2016). Further evidence from SSCP and ITS DNA sequencing support Trypanosoma evansi and Trypanosoma equiperdum as subspecies or even strains of Trypanosoma brucei. Infection, Genetics and Evolution 41:56-62. https://doi.org/10.1016/j.meegid.2016.03.022
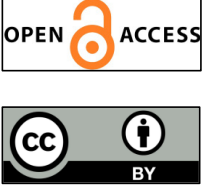

The journal offers free, immediate, and unrestricted access to peer-reviewed research and scholarly work. Users are allowed to read, download, copy, distribute, print, search, or link to the full texts of the articles, or use them for any other lawful purpose, without asking prior permission from the publisher or the author.

License - Articles published in Notulae Scientia Biologicae are Open-Access, distributed under the terms and conditions of the Creative Commons Attribution (CC BY 4.0) License.

(c) Articles by the authors; SHST, Cluj-Napoca, Romania. The journal allows the author(s) to hold the copyright/to retain publishing rights without restriction. 